\title{
Relationship between nutritional status and eruption of first permanent mandibular molar teeth among the school children in Indonesia
}

\author{
Syukra Alhamda \\ Lecturer, Health Polytechnic at Dental Nursing Academy, West Sumatera, Indonesia.
}

\section{Letter to Editor}

The aims of the 'Indonesia Healthy 2010' program were to develop sound national health, encourage people to live healthy and self-reliance, increase healthcare quality, and improve the health of individuals, families and communities along their environtment. ${ }^{1}$ However, public health issues and nutritional problems in Indonesia still need to be tackled in an integrated manner, especially in vulnerable groups. The prevalence of malnutrition among school -age children is $36.1 \%$; elementary school children are the most vulnerable group suffered health problems due to malnutrition. ${ }^{2}$ According to the Ministry of Health survey, nearly $50 \%$ of elementary school students were malnourished in Indonesia. ${ }^{2}$

A balanced diet contains all the elements necessary for the growth of the teeth; malnutrition in children can lead to a variety of teeth disorders. ${ }^{3}$ The first permanent teeth are the first molars which appear between 6-7 years. The first permanent molar teeth are very important and are called the "Keystones of Dental Arch" which means that the shape of the mouth of a child depends on the size of teeth. ${ }^{4}$ The first permanent teeth are also important as it stimulates the grow of the jaw. ${ }^{5}$

Nutritional deficiencies can lead to delays in the process of teeth eruption. The aim of the study was to investigate the relationship between the nutritional status and the permanent eruption of the first molar teeth of elementary school students aged 6-7 years in the Lintau Buo District, Tanah Datar regency, Indonesia. The cross-sectional study was carried out from September to October 2011 among 412 elementary school pupils from 10 schools. The nutritional status of the children was determined by measuring weight, height and body mass index (BMI) of the school children according to the classification of BMI for children. ${ }^{6}$ The data was analyzed using Microsoft Excel.

Among the 412 children, 204 (49.5\%) were male and 208 $(50.5 \%)$ were female, with a mean age of 6.75 years. The findings showed that more than half of the children (51.2\%) had normal BMI. It was also found that $45.4 \%$ students were underweight and more male students $(24.6 \%)$ were underweight than female students $(20.8 \%)$. In $360(87.4 \%)$ children, the mandibular first molar teeth were erupted (Table 1). It was also found that the mandibular first molar teeth were erupted in 197 (93.4\%) students with a normal BMI and 149 (79.7\%) students who were underweight.

The overall findings of the study showed that approximately half of the children of the Lintau Buo district suffered from nutrition deficiency which may be the cause of delay in the eruption of the mandibular first molar teeth. The study showed that there is a significant association between nutritional status with the eruption of permanent first molars $(p=0.000 ; \mathrm{r}=0.389)$ in elementary school pupils. The study also demonstrated that the first molars were not erupted in more that $20 \%$ of underweight students in comparison to $6.6 \%$ students with a normal BMI. Malnutrition and poor nutrition in early childhood affects tooth eruption and results in the delayed emergence of the teeth. However a study conducted by Boenjamin et al. ${ }^{7}$ in Jakarta showed no association between nutritional status with the eruption of permanent first molar teeth.

The population of the Lintau Buo district has a low educational and socioeconomic status and the health service in this area is still not evenly distributed because there are still remote villages where very difficult to reach and providing appropriate healthcare proved to be difficult. Factors which affect the nutritional status of children include food intake, food availability, feeding practices of infants and toddlers, knowledge and awareness of health education, utilization of health service, and health and environment sanitation. ${ }^{3,8}$ General malnutrition can cause interference with the process of growth, energy production, body's defenses, the structure and function of brain and behaviour. ${ }^{5}$ The teeth eruption is influenced by several factors which include nutritional, hormonal, hereditary or genetic factors. ${ }^{7}$ Socioeconomic and nutritional factors, caries conditions and the secular trend have also been found to have some effect on the eruption of permanent teeth. ${ }^{9,10}$ Teeth are a small part of the bone, the formation being initiated from within the womb. Nutrition is one important factor for the growth of the teeth and will affect the eruption of permanent teeth. ${ }^{11,12}$ Various kinds of nutrients play an important role in the formation and growth of the teeth, which took place in the womb until the maturation of the teeth so it can

Correspondence: Syukra Alhamda, Lecturer, Health Polytechnic at Dental Nursing Academy, Panorama Baru Street 26 ${ }^{\text {th }}$ Bukittinggi 26123, West Sumatera, Indonesia. E-mail: syukra909604@gmail.com. 
Table 1: Relationship between nutritional status with eruption of the first permanent mandibular molar teeth in school children

\begin{tabular}{|l|c|c|c|}
\hline \multirow{2}{*}{ BMI classification } & \multicolumn{2}{|c|}{ Teeth eruption } & \multirow{2}{*}{-value } \\
\cline { 2 - 3 } & Erupted & Not erupted & $p=0.000$ \\
\hline Underweight & $149(79.7 \%)$ & $14(6.6 \%)$ & $p=0.000$ \\
\hline Normal & $197(93.4 \%)$ & 0 & $p=0.050$ \\
\hline Overweight & $6(100 \%)$ & 0 & $p=0.050$ \\
\hline Obese & $8(100 \%)$ & $0.3 \%)$ & \\
\hline
\end{tabular}

*Values are significant $p<0.05$.

function in the oral cavity, whether it be milk teeth or permanent teeth. Therefore, necessary efforts should be taken to improve the nutritional status of children in infancy, especially the growth of the teeth in order to obtain an optimal state of oral hygiene including tooth eruption of the permanent molar.

Local governments should prioritize the development of health sectors in more remote villages, including the development of the health of elementary school students so as to create a young healthy generation. Initiatives should be undertaken for health promotion among the students, teachers and parents regarding oral health and healthy eating.

\section{References}

1. Department of Health Republic of Indonesia. Indonesia Sehat 2010. Jakarta: Department of Health, 2009.

2. Moehji S. Nutritional Science I. Jakarta: Papas Sinar Sinanti, 2002.

3. Department of Health Republic of Indonesia. Teeth and healthy. Health Mag, 2006;170:66.

4. Srigupta AA. Healthcare of mouth and teeth. Jakarta: Prestasi Pustaka Publisher, 2004.
5. Situmorang N. Satisfaction survey in teeth and mouth health care at Health Centre, Medan. Dentika Dent J 2006:1:100.

6. Australian Bureau of Statistics. Australian Health Survey: Users' Guide, 2011-13: Classification of BMI for children. Appendix 4. http:// www.abs.gov.au (accessed Dec 2012)

7. Boenjamin, Situmorang N, Nasution L. Malnutrition. Dentika Dent J 2006:1:110.

8. Schuurs DKK. Pathology of teeth. Yokyakarta: Gadjah Mada University Press Yokyakarta,1992.

9. Eskeli R, Laine-Alava MT, Hausen H, Pahkala R. Standards for permanent tooth emergence in Finish children. Angle Orthodontist, 1999; 69:529-33.

10. Alvarez JO, Navia JM. Nutritional status, tooth eruption and dental caries. Am J Clin Nutr 1989; 49: 417-26.

11. Sediaoetama AD. Nutritional Science II. Jakarta: Dian Rakyat, 2006.

12. Supartinah AS. Role in growth of brushing microorganisms oral cavity. Yogyakarta: IKGAI, 1999. 